\title{
MERCOSUR: A Cautionary Tale
}

\author{
Clara Downey, University of Texas-Brownsville, USA
}

\begin{abstract}
Regional economic integration has resulted from the globalization phenomena. Nations establish trade blocs as a strategic maneuver, while firms seeking growth and investment opportunities require knowledge of prevailing business laws. Prudent, integrated policy-making will support the trade bloc's interactions and provide firms with a sense of certainty. The business bankruptcy laws of South America's largest trade bloc, MERCOSUR, are investigated to determine if they are moving toward alignment that would foster growth within the association and attract foreign investors.
\end{abstract}

Keywords: MERCOSUR; Bankruptcy Laws; Economic Regional Integration; Trade Bloc

\section{INTRODUCTION}

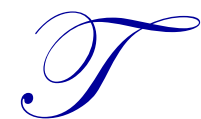

he strategic assessment process is critical to all firms investigating market growth opportunities, especially in emerging markets (Khanna, Palepu, \& Sinha, 2005; Li, Poppo, \& Zhou, 2008). From a strategic perspective, nations should implement consistent policies as a safeguard from the adverse impact of global pressures (Agbetsiafa, 2011; Beraho \& Elisu, 2010; Fishlow, 2013). Although a complete review of all risks associated with entering a market is beyond the scope of this paper, the assessment of national- and regional-level risks is a necessary part of the strategic management process (Rangan \& Drummond, 2004). Within the context of national- and regional-level risks, the legal infrastructure, and thereby market stability, should be assessed (Barney \& Hesterly, 2006; Deresky, 2014; Rangan \& Drummond, 2004). For example, a nation's bankruptcy laws are an essential consideration (Araujo \& Funchal, 2005; Araujo, Ferreira, \& Funchal, 2012; Holt, 2007; LeMaster, Downey, \& Brewerton, 2007; Tanzi, 2004). This investigation is critical since the management of cross-border bankruptcies is garnering increasing attention (Evans \& Borders, 2013; Filho, 2009; Mason, 2012).

For an economy to achieve efficiencies, it must have effective institutions (Araujo et al., 2012; Tanzi, 2004). The presence of a modern bankruptcy process is instrumental to the way a nation distributes its available resources (Stone, 2010) and responds to financial issues (Beraho \& Elisu, 2010). In addition, this will assist multinational corporations seeking opportunities to understand the current state of affairs in these nations (Alli, Winter, \& May, 2007; Blodgett \& Kane, 2003; Evans \& Borders, 2013; Holt, 2007). Furthermore, the presence of certainty created by legal mechanisms will attract investment (Holt, 2007; Kleinheisterkamp, 2000; Yong, 2010).

As developing economies engage in the global market, their legal structures, specifically bankruptcy laws, must provide an ease of entry for foreign entrants and foster an environment for development (Araujo \& Funchal, 2005; Blodgett \& Kane, 2003; Fishlow, 2013; Mason, 2012; Khanna et al., 2005). Nations develop bankruptcy laws to remedy economic issues and can differ greatly from one another (Beraho \& Elisu, 2010; Lee, Yamakawa, Peng, \& Barney, 2011). Each country is unique in the development timeline and structure of their legal system and is usually not in perfect alignment with their neighbor. As a result of globalization, trade blocs are created around commerce agreements to increase trade and drive growth (Castanias \& Yelamanchi, 2004; Gough \& Venkataramany, 2006). A key component to the bloc's success is coordination of legislation (Haskel, 2013).

Large economic blocs are more attractive for foreign investment and require additional investigation (Hashmi, 2012). The trade bloc MERCOSUR represents substantial economic weight for South America. The purpose of this paper is to investigate the current state of the MERCOSUR members' prevailing laws, specifically governing business bankruptcy proceedings (Yong, 2010). Of interest is the enquiry into whether the nations are moving their polices into alignment. This paper contributes to a greater understanding of the prevailing business 
and investment conditions with a focus on examining developing economies (Araujo et al., 2012; Khanna et al., 2005; Lee et al., 2011; Li et al., 2008). As the MERCOSUR members grow, they will require an alignment of and adherence to regulatory policies or seek opportunities independently (Fishlow, 2013). Furthermore, this paper provides a framework to study other economic trade blocs.

Remaining sections of this paper consist of an explanation of the economic integration as a result of globalization, an introduction of a conceptual framework as an analysis tool, a presentation of the current status of MERCOSUR members' business insolvency laws, and a discussion of the implications followed by conclusions.

\section{GLOBALIZATION LEADS TO ECONOMIC INTEGRATION}

Globalization is defined as "global competition characterized by networks of international linkages that bind countries, institutions, and people in an interdependent global economy" (Deresky, 2014, p. 4). The globalization phenomenon requires nations to develop policy responses to shifting market demands. A competitive marketplace propels nations of all sizes to create functional regional economic organizations to better meet the challenges present in the interconnected global economy (Cordoba, 2012).

Economic integration is defined as "the lessening of trade barriers and the increased flow of goods and services, capital, labor, and technology" (Deresky, 2014, p. 4). This integration is illustrated by increasing levels of economic interconnectedness delineated in five levels as follows: free trade area, customs union, common market, economic union, and political union (Cavusgil, Knight, \& Riesenberger, 2012). At one end of the spectrum, a free trade area does not uphold unified trade barriers with non-members; NAFTA is an example. Continuing along the spectrum, the economic union maintains a goal for members to achieve relative monetary and fiscal policies - the European Union (EU) is an example (Cavusgil et al., 2012). On the other end of the spectrum, political union is defined as a complete merging of all policies and is only discussed theoretically.

The objective of integrating economies is to increase the exchange of market participants, services, and products by decreasing trade barriers (Alli et al., 2007; Deresky, 2014). For example, utilizing regional-based relationships will assist navigating the changing economic landscape (Alli et al., 2007; Bisson, Kirkland, \& Stephenson, 2010; Cordoba, 2012). These trade blocs represent commerce agreements that support increased trade and fuel globalization (Castanias \& Yelamanchi, 2004; Gough \& Venkataramany, 2006). The integration can be fostered by geographic proximity, which is known as regional integration (Cavusgil et al., 2012). Furthermore, regional-level cooperation in developing economies, specifically Latin America, is necessary to grow domestic markets, export strength, and attract trade partners (Gough \& Venkataramany, 2006).

MERCOSUR is considered "the fourth largest trading bloc after the EU, NAFTA, and ASEAN", along with accounting for "75 percent of South America's GDP" (Deresky, 2014, p. 16). With the admission of Venezuela in 2012, the trading bloc "became the world's fifth-largest economy" (Keller, 2012, p. 1). Furthermore, it is the largest economic trading bloc in South America (Cavusgil et al., 2012; Lawrence, Hanouz, \& Doherty, 2012). Considering the economic might of MERCOSUR, it has not made substantial progress aligning its policies, thereby hindering its progress (Canac, 2003; Fishlow, 2013; Yong, 2010).

For developing nations, it should be imperative to enact strong policy during growth periods (Agbetsiafa, 2011; Fishlow, 2013). Nations will increase their economic interconnectedness by engaging in trade with fellow countries because it is a strong impetus for growth (Alli et al., 2007; Castanias \& Yelamanchi, 2004; Fishlow, 2013; Gough \& Venkataramany, 2006). The recognition of the importance of allowing the movement of a nation's factors of production across borders seamlessly is a critical step in responding to the realities of globalization (Bisson, et al., 2010). For example, firms will take advantage of this environment and outsource various activities as a strategic maneuver that requires knowledge of foreign governments and their regulatory schemes (Alli et al., 2007; Sen \& Haq, 2010). As a strategic measure, nations should pursue consistent policies to mitigate the negative impact resulting from global pressures (Agbetsiafa, 2011; Beraho \& Elisu, 2010), whereas from the firm-level perspective, globalization will extend activities and assets across borders (Mohan, 2012). A critical infrastructure to support the integration of developing economies is that legal structures governing business bankruptcy must harmonize (Blodgett \& Kane, 2003). The scope of a nation's bankruptcy laws is an essential element to creating an environment for firm growth (Holt, 2007; Lee et al., 2011; Mason, 2012). 


\section{TERRITORIALISM AND UNIVERSALISM}

Territorialism provides that an individual country maintains jurisdiction regarding a firm's bankruptcy proceedings inside its national borders (LoPucki, 1999). Foreseeably, a foreign investor's assets could be consumed by the bankruptcy procedure in that foreign country (Filho, 2009). Conversely, Universalism allows a single court to administer a firm's insolvency proceedings on a global level with assistance from the involved countries (Westbrook, 2002). Theoretically, this may imply a single court to administer a universal group of bankruptcy laws; establishing this framework is not realistic in the near future (Rasmussen, 2007).

As a means toward cooperation, Comity is a principle which stipulates that "one nation gives effect to the laws and judicial decisions of another nation as a matter of deference and mutual respect" (Holt, 2007, p. 106). The author argues that Universalism supports this principle, while Territorialism does not require this framework. The concepts of Universalism and Territorialism are utilized as a backdrop to analyze the prevailing bankruptcy laws of MERCOSUR members (LeMaster et al., 2007).

At nation-level policy-making, thereby, government intervention is a key element to success. Tanzi (2004) and Araujo et al. (2012) argued that functioning economies require efficient institutions, specifically systems to facilitate bankruptcy with transparency. The reality of cross-border bankruptcy can result in great financial and time resource commitment (Mohan, 2012). Conversely, given the presence of legal mechanisms that create certainty, foreign investment will be attracted (Holt, 2007; Kleinheisterkamp, 2000; Yong, 2010). The agreement to adopt cross-border bankruptcy laws will create a more efficient and favorable environment for investors (Blodgett \& Kane, 2003; Holt, 2007; Mason, 2012).

As world-wide competition increases, cross-border economic pacts will result (Deresky, 2014). A key component to the bloc's success is coordination of legislation (Haskel, 2013), supported by governments intervening with prudent polices (Bisson et al., 2010; Lee et al., 2011). In reality, members should normalize regulations among members to foster economic exchange (Keller, 2012).

For example, there is a distinction between an insolvent and illiquid firm. While the insolvent firm will proceed to liquidation, the illiquid firm may survive following a reorganization process (Olivares-Caminal \& Frigerio, 2009). The reorganization procedure is critical to salvage a firm, especially in developing economies (Araujo \& Funchal, 2005). With companies extending their activities and investments across borders, the prevailing reorganization procedure will be of importance (Filho, 2009). Furthermore, the ability to negotiate out-of-court (e.g., private) settlements and determine the priority of claims provides investors and creditors a certain level of predictability (Olivares-Caminal \& Frigerio, 2009). The presence of a modern rehabilitation process allows firms to efficiently navigate the bankruptcy process (Stone, 2010).

In order for nations to operate within a group, a supranational framework is required to assist members to coordinate their economic activities (Canac, 2003; Yong, 2010). The adoption and adherence to a unifying bankruptcy legal framework will address the issue of jurisdiction, thereby fostering a sense of certainty critical to attract investment, create market efficiencies, and promote growth (Holt, 2007; Khanna et al., 2005). This commitment will immensely assist the trade bloc to achieve growth within the group and moving outward as a unified entity.

\section{MERCOSUR MEMBERS}

\section{Southern Common Market or Common Market of the South}

In 1988, the governments of Argentina and Brazil entered into a free trade agreement that eventually grew into MERCOSUR with an ultimate goal to create a common market (Hill, 2013; Keller, 2012). MERCOSUR was formally established in 1991 (Canac, 2003; Cavusgil et al., 2012) to embody economic and political agreements (Klonsky, Hanson, \& Lee, 2012). 
MERCOSUR is considered a customs union (Cordoba, 2012; Haskel, 2013; Keller, 2012) because it is integrated on a regional level and the members have committed to harmonizing "their external trade policies and adopt common tariff and nontariff barriers on imports from nonmember" nations (Cavusgil et al., 2012, p. 229). A resulting goal was to create a competitive advantage by increasing efficiencies and capitalizing geographic proximity ("About Mercosur", n.d.; Canac, 2003). In Latin America, several nations have revised their bankruptcy codes (Olivares-Caminal \& Frigerio, 2009).

The full members of MERCOSUR are Brazil, Argentina, Uruguay, Paraguay, and Venezuela. The Associate members are Bolivia, Chile, Colombia, Ecuador, and Peru (Klonsky et al., 2012). Associate members are not included in this analysis because until full integration is achieved, they are not receiving tariff benefits (Cavusgil et al., 2012) and lack voting rights (Keller, 2012; Klonsky et al., 2012). In the future, MERCOSUR's economic might will grow with their inclusion (de Castro Neves, 2013). Currently, membership in other trade bloc precludes nations from full membership (Cordoba, 2012; Desantis, 2013; Klonsky et al., 2012).

The bankruptcy laws of the full members will be assessed, along with providing a brief status of each member. A summary of these items is provided in Table 1. The prevailing bankruptcy laws are discussed as to whether they acknowledge foreign investment, provide for a reorganization and/or private settlement process, and stipulate the priority order of creditor claims.

The majority of national bankruptcy laws allow for the liquidation and/or reorganization process. Although a dire financial condition of some firms requires the liquidation of the assets, other firms can be saved. In essence, the reorganization process allows a firm to continue operations while restructuring their debt (Araujo \& Funchal, 2005). The goal of efficient bankruptcy procedures should ensure that creditors are protected and prioritized (Hart, 2000).

Table 1: Individual MERCOSUR Member's Bankruptcy Law Provisions

\begin{tabular}{|l|c|c|c|c|}
\hline \multicolumn{1}{|c|}{ Country } & $\begin{array}{c}\text { Foreign Investment } \\
\text { Legally Acknowledged }\end{array}$ & Reorganization & $\begin{array}{c}\text { Creditor Claim } \\
\text { Ranking Provided }\end{array}$ & $\begin{array}{c}\text { Out of Court } \\
\text { Settlement Available }\end{array}$ \\
\hline Argentina & $\mathrm{X}$ & $\mathrm{X}$ & $\mathrm{X}$ & $\mathrm{X}$ \\
\hline Brazil & $\mathrm{X}$ & $\mathrm{X}$ & $\mathrm{X}$ & $\mathrm{X}$ \\
\hline Paraguay & $\mathrm{X}$ & $\mathrm{X}$ & $\mathrm{X}$ & $\mathrm{X}$ \\
\hline Uruguay & $\mathrm{X}$ & $\mathrm{X}$ & $\mathrm{X} / \mathrm{A}$ & $\mathrm{N}$ \\
\hline Venezuela & $\mathrm{N} / \mathrm{A}$ & $\mathrm{N} / \mathrm{A}$ & \\
\hline
\end{tabular}

Argentina

Argentina has recently implemented many state-controlled economic policies (Fishlow, 2013; "Latin American Geoeconomics", 2013). Specifically, the administration appears to favor strategic economic sectors with protectionist measures (Country Conditions: Argentina, 2013). Also, the nation's continuing issues with Britain regarding the Falkand Islands further thwart the bloc's conversations with external markets (Cordoba, 2012; "Latin American Integration," 2013). As a result, the nation is not aligning with the overall policies of MERCOSUR (Haskel, 2013).

Argentina welcomes foreign investment and allows for equal treatment for those assets (Alfaro, Mazer, \& Abogados, 2013). The Argentine Bankruptcy Law (Law 24.522) governs the bankruptcy process. The Law allows the debtor firm to reorganize while continuing operations or seeking a private (e.g., out-of-court) settlement with debtors (Alfaro et al., 2013). Furthermore, creditors are granted privileged status to those holding wages, taxes, and mortgage claims (Willa \& Roca, 2013). In a turn away from the traditional insolvency process, employees of a cooperative supersede creditors by requesting the firm to continue as a going concern (Alfaro et al., 2013; "New Argentine Bankruptcy Law,” 2011).

Brazil

Brazil is considered the largest economy in Latin America and globally ranks fifth in population and seventh in size of economy (Deresky, 2014). Due to its size, the nation tends to represent the other MERCOSUR 
countries (Lawrence et al., 2012). Although it is attractive to foreign investors (Roett, 2010), Brazil has lost some competitiveness and risks isolation from the larger, global economy. This is attributed to prevailing policies sending mixed signals to potential investors, as the country appears to focus on domestic economic issues rather than reforming trade programs ("Latin American Geoeconomics," 2013).

Brazil is open to foreign investment and affords equal protection for those assets (Mussnich \& Peres, 2013). In 2005, a new bankruptcy law was enacted (Law 11.101) which allows a firm to remain in operation while it reorganizes debt, liquidates its assets, or seeks a private settlement. Furthermore, the creditors are classified in categories per priority (Rosas \& Nogueira, 2013).

\section{Paraguay}

Paraguay is the smallest member of the MERCOSUR trading bloc and was suspended in 2012 (Desantis, 2013; Klonsky et al., 2012). The suspension was based on fellow members deeming the impeachment of the nation's previous president, Mr. Lugo, as unjust. The impeachment was seen as violating MERCOSUR's democracy clause (Badawy, 2013; Keller, 2012). The nation was offered reinstatement upon the inauguration of a newly-elected president, Mr. Cartes. Paraguay has long objected to Venezuela's admission to the bloc (Badawy, 2013; Keller, 2012), so the country has declined reinstatement until the MERCOSUR presidency rotates away from Venezuela in July 2014 ("Paraguay's President," 2013). Current President Cartes remains hopeful that his country will rejoin the bloc as early as 2014 (Badawy, 2013; Desantis, 2013).

Paraguay welcomes foreign investment and provides equal treatment for those assets (Country Conditions: Paraguay, 2012, 2013). The Law 117/91 includes the commercial bankruptcy process and provides "priority for claims first to employees, then to the state, and finally to private creditors" (Country Conditions: Paraguay, 2012, p. 5). The debtor firm is allowed to reorganize while continuing operations or seeking settlement with debtors or liquidation with court approval (Brown, 2013).

\section{Uruguay}

MERCOSUR membership is instrumental to Uruguay's economic development ("Uruguay calls on Mercosur", 2013). In light of this, the country has encountered trade issues with another bloc member. Although other economic sectors, such as mining, are in development, tourism is an important area for exchange, especially with fellow MERCOSUR member, Argentina. Given Argentina's recent tax increase governing tourism, the relationship with Uruguay has been weakened ("Where is Uruguay's," 2013).

Uruguay welcomes outside investment and gives equal treatment for those assets (Country Conditions: Uruguay, 2013). In 2008, the government instituted a new law (Act 18.387) regarding the bankruptcy process. Specifically, the Act allows the debtor firm to reorganize while continuing operations, to seek a private settlement with debtors or asset liquidation with court approval (Guerrero \& Gurmendez, 2013). Furthermore, the Act limited creditors who sought privileged status to those holding secured loans, taxes and labor credits and honoring the entity who initiated the action (Beitler, n.d.).

Venezuela

Venezuela joined MERCOSUR as a full member in July 2012. Its admission has created tension among members because its governmental actions indicate an opposition to a free market system (Klonsky et al., 2012; Martinez \& Iyer, 2013). Specifically, Venezuela's economy is dominated with state-controlled policies (Fishlow, 2013; Hill, 2013; Klonsky et al., 2012; "Latin American Geoeconomics," 2013; Martinez \& Iyer, 2013). Furthermore, it is an economy that is dependent on one industry - oil (Haskel, 2013). The continual government interference with economic and political policies may hinder meeting MERCOSUR's requirements and 2014 deadline (Keller, 2012). Furthermore, it is argued that the nation's inclusion in the bloc was politically, not economically, motivated (Haskel, 2013).

Theoretically, foreign investment is allowed in Venezuela; however, recent events indicate otherwise. Beginning in 2009, foreign investment began to sharply decline due to the uncertain environment. This period is 
marked by increasing government intervention, nationalization, and expropriation impacting many industries (Country Conditions: Venezuela, 2013). Currently, the prevailing bankruptcy laws are considered too antiquated to allow judicial-governed reorganization, thereby encouraging private arrangements (Italiani, 2013).

\section{DISCUSSION}

As competition world-wide increases, cross-border economic pacts will result (Deresky, 2014). In order for a nation to succeed in the globalizing and interdependent marketplace, it must intervene with prudent polices (Bisson et al., 2010). For example, it should synchronize its macroeconomic procedures (Canac, 2003; Cordoba, 2012; Haskel, 2013). This economic integration and harmonization will create a reliable environment that is advantageous for investment (Kleinheisterkamp, 2000; Yong, 2010). These growing economies require efficient institutions by promoting transparency (Tanzi, 2004). With prudent policy implementation, nations strategically attempt to minimize negative impacts from global financial interconnectedness (Agbetsiafa, 2011; Beraho \& Elisu, 2010; Kleinheisterkamp, 2000). An additional benefit is the creation of a sense of predictability for necessary investment and trade growth (Fishlow, 2013; Holt, 2007; Kleinheisterkamp, 2000; Yong, 2010; Gough \& Venkataramany, 2006).

The net result of globalization is that firms will extend activities and assets across borders (Mohan, 2012). Bankruptcy can be an inherent result of the risk involved in business development, and this event is common (Lee et al., 2011). The removal of inefficient firms from the market will serve an economies' growth by freeing critical resources (Stone, 2010). Although bankruptcy laws differ greatly from one another, they should serve to respond to financial issues (Beraho \& Elisu, 2010; Lee et al., 2011). Given the current trend of economic integration and desiring growth, developing nations will be required to move toward a unifying framework to provide investors a sense of certainty. The quest for a single unifying framework, such as Universalism, may be in vain, as Holt (2007) acknowledges that many nations will resist adhering to such strict tenets. Given that trade blocs can evolve in an inconsistent manner, they still warrant investigation (Castanias \& Yelamanchi, 2004).

\section{MERCOSUR}

As the South American economies continue to develop, regional-level cooperation is required to foster domestic market growth and exporting strength (Gough \& Venkataramany, 2006). The concept of regional integration is supported by members sharing geographic and economic commonalities (Castanias \& Yelamanchi, 2004; Cavusgil et al., 2012). Since the MERCOSUR nations share similar languages and cultures, this commonality should serve as an advantage when compared with other trade blocs (Gough \& Venkataramany, 2006). In the early years of MERCOSUR, it was economically successful with "trade between the four core members quadrupled" (Hill, 2013, p. 303). As a direct result of the economic interconnectedness, specifically Brazil's economic downturn in 1998 and 1999, the trade bloc was negatively impacted (Hill, 2013; Vigevani \& Júnior, 2011). Along with the economic downturn, continued inner disagreements among members halted progress toward achieving a fully functioning customs union (Cordoba, 2012; Hill, 2013). There are mixed assessments of the bloc as some argue that MERCOSUR appears to be isolating, rather than opening (Haskel, 2013; Osava, 2013), while others suggest that the member nations should seek outside opportunities and engage in other beneficial trade associations ("Uruguay Calls on Mercosur," 2013).

A key component to the bloc's success is coordination of legislation; unfortunately, the members appear to lack unification. For example, Brazil and Argentina desire higher tariffs, whereas Uruguay and Paraguay prefer decreasing the barriers (Keller, 2012). Canac (2003) and Fishlow (2013) suggest that in the absence of alignment within the group, individual nations will pursue their own developmental paths. Recently, Brazil has grown its export relationship with China (de Castro Neves, 2013; Deresky, 2014; Martinez \& Iyer, 2013), along with engaging with Cuba in medical exchanges ("Latin American Geoeconomics," 2013). The heightened trade relationship with China may be a possible explanation for Brazil's lack of consistent movement forward in pursuing greater integration with the other MERCOSUR members. For the bloc, Brazil's redirection is an unfortunate maneuver since it is pivotal in the group's success (Osava, 2013).

Alignment of foreign policy and adopting growth-enhancing strategies are required for realistic integration; unfortunately, individual nations clinging to internalizing tendencies can thwart the alignment (Vigevani \& Júnior, 
2011). Currently, some members appear committed to their internal policies, not harmonizing the bloc's legal framework (Haskel, 2013). For example, Venezuela poses several serious issues. The economy is dominated with state-controlled policies exemplifying opposition to a free market system and is highly depended on a single industry - oil (Klonsky et al., 2012; Haskel, 2013; "Latin American Geoeconomics," 2013; Martinez \& Iyer, 2013).

Bankruptcy legal structures must harmonize to allow foreign investment and support internal growth of developing countries that want to enter the global marketplace (Blodgett \& Kane, 2003; Holt, 2007). The MERCOSUR members' business bankruptcy laws were assessed to determine the bloc's alignment. Four of the members - Argentina, Brazil, Paraguay, and Uruguay - have established modern bankruptcy laws to acknowledge and protect foreign investment, allow insolvent firms to reorganize operations, rank creditor claims, and provide for private settlements. The current nationalistic climate in Venezuela does not afford foreign and domestic businesses much confidence for investment protection. Although most members have made progress modernizing their bankruptcy procedures, they tend to uphold a Territorial perspective.

Globalization can threaten a nation's sovereignty, thereby supporting a resistance to consolidating economic (Cavusgil et al., 2012) and legal systems (Holt, 2007). The relinquishment of national sovereignty by coordinating legal systems has impeded integration (Cordoba, 2012; Haskel, 2013; Yong, 2010); however, harmonization is necessary for economic survival (Blodgett \& Kane, 2003). This inability to reconcile differences among the members could ultimately encumber the achievement of a customs union as members implement protectionist policies (Cordoba, 2012; de Castro Neves, 2013; Klonsky et al., 2012).

Until recent events, the MERCOSUR members' activities appeared to shift away from their original economic goals and become muddied with political initiatives (Haskel, 2013; Klonsky et al., 2012; "Latin American Geoeconomics," 2013). This dysfunction is exemplified by MERCOSUR's inability to proceed with trade talks with the EU (Cordoba, 2012; de Castro Neves, August 14, 2013; "Latin American Geoeconomics," 2013; Latin American Integration, 2013). Recently, Brazil has announced the bloc's desire to actively negotiate a trade agreement with the EU ("Brazil Trade Council Approves," 2013; Desantis, 2013) which was supported by the Uruguayan president ("Mercosur Remains," 2013). However, investors and interested parties alike should view these statements with caution. In a rhetorical assessment of MERCOSUR, it is noted that the bloc's only recent unified action was to suspend Paraguay ("Latin American Integration," 2013).

\section{CONCLUSIONS}

Firms will seek strategic foreign investment opportunities and developing nations require the infusion of foreign capital. It is critical to assess the country- and regional-level risks, especially the prevailing bankruptcy laws. The trade bloc, MERCOSUR, represents a large economic force in the global marketplace and should not be ignored. Furthermore, its strength will grow as associate members join. Although there is hope that the bloc will move toward acting as a unified entity as it proceeds with trade negotiations with the EU, the current landscape should be viewed with caution. Until recently, the individual members were enacting protectionist policies rather than making objective efforts toward legal integration.

This paper argued that moving toward a common set of harmonizing bankruptcy laws would assist to create a favorable investor climate, along with encouraging domestic growth. Since the MERCOSUR members are developing nations, it is critical to implement strong policies during positive growth periods; otherwise individual members will pursue opportunities elsewhere. It is acknowledged that the bloc members have made progress toward modernizing their business bankruptcy procedures; however, they are not integrated. Their progress has been halted by political and economic conflicting agendas. By moving beyond these impediments, an alignment among regional economies would serve to drive internal and external growth. It is suggested that the bloc members work toward a supranational legal framework that would provide greater transparency, investor confidence, and integration. This alignment will provide a framework for future investigations of other economic trade blocs.

\section{ACKNOWLEDGEMENT}

The author would like to thank Todd S. for his immeasurable inspiration. 


\section{AUTHOR INFORMATION}

Clara Downey, Ph.D., has over ten years of private industry experience in the insurance industry, working in the Midwest, Bay Area, and Asia. She completed a Ph.D. in Business Administration and holds a M.B.A. in International Management from Thunderbird Graduate School in Arizona. Her undergraduate degree in East Asian Studies is from Indiana University, Bloomington. Research areas include international strategic alliances, business bankruptcy, and consumer behavior. E-mail: claradowney@gmail.com

\section{REFERENCES}

1. About Mercosur. (n.d.) MercoPress: South Atlantic News Agency. Retrieved from http://en.mercopress.com

2. Agbetsiafa, D. K. (2011). The recent global financial crisis: Impacts on selected developing regions. International Business \& Economics Research Journal, 10(10), 93-101.

3. Alfaro, C., Mazer, P., \& Abogados, A. (2013, February 25). Argentina. (Mergers and Acquisitions 2013). Retrieved from http://latinlawyer.com/reference/topics/55/mergers-acquisitions

4. Alli, A., Winter, G., \& May, D. (2007). Globalization: Its effects. International Business \& Economics Research Journal, 6(1), 89-95.

5. Araujo, A., \& Funchal, B. (2005). Bankruptcy law in Latin America: Past and future. Economia, 6(1), 149216.

6. Araujo, A., Ferreira, R., \& Funchal, B. (2012). The Brazilian bankruptcy law experience. Journal of Corporate Finance, 18(4), 994-1004.

7. Badawy, M. (2013, September 23). Exclusive: Paraguay, Venezuela to meet on Mercosur. Reuters. Retrieved from http://uk.reuters.com

8. Barney, J., \& Hesterly, W. (2006). Strategic management and competitive advantage: Concepts and cases. Upper Saddle River, N.J.: Pearson Prentice Hall.

9. Beitler, A. (n.d.). Uruguay: Financial regulation and access to credit. (Ferrere report). Retrieved from http://www.iflr1000.com

10. Beraho, E. K., \& Elisu, R. (2010). Influence of country culture on bankruptcy and insolvency legal reform management. International Journal of Management \& Information Systems, 14(2), 39-49.

11. Bisson, P., Kirkland, R., \& Stephenson, E. (2010, June). The Market State. (Insights \& Publications). Retrieved from http://www.mckinsey.com

12. Blodgett, M. S., \& Kane, S. A. (2003). Global corporate governance: Implications for a functionally harmonized legal infrastructure. Journal of Business \& Economics Research, 1(6), 19-25.

13. Brazil Trade Council Approves Proposed Offer in EU/Mercosur Trade Talks. (2013, October 3). Wall Street Journal. Retrieved from http://online.wsj.com

14. Brown, S. G. (2013, February 25). Paraguay. (Mergers and Acquisitions 2013). Retrieved from http://latinlawyer.com/reference/topics/55/jurisdictions/46/paraguay

15. Canac, P. (2003). A new financial architecture for South American countries. International Business \& Economics Research Journal, 2(9), 65-74.

16. Castanias, R. P., \& Yelamanchi, Y. (2004). Who benefits and who loses from the regionalization of world trade? International Business \& Economics Research Journal, 3(9), 1-14.

17. Cavusgil, S. T., Knight, G., \& Riesenberger, J. R. (2012). International business: The new realities. (Second edition). Prentice Hall. Upper Saddle River, New Jersey.

18. Cordoba, N. (2012). Snapshot of MERCOSUR and the EU. Retrieved from http://www.eiiw.eu/fileadmin/eiiw/Daten/Publikationen/Sonstiges/MERCOSUR_EU-TRADE.pdf

19. Country Conditions: Argentina. (2013). Political Risk Yearbook: Argentina Country Report, 1-18.

20. Country Conditions: Paraguay. (2013). Political Risk Yearbook: Paraguay Country Report, 1-9.

21. Country Conditions: Paraguay. (2012). Political Risk Yearbook: Paraguay Country Report, 1-11.

22. Country Conditions: Uruguay. (2013). Political Risk Yearbook: Uruguay Country Report, 1-13.

23. Country Conditions: Venezuela. (2013). Political Risk Yearbook: Venezuela Country Report, 1-21.

24. de Castro Neves, J. (2013, August 14). Mercosur's expansion sows seeds of slow decline. World Politics Review. Retrieved from http://www.worldpoliticsreview.com

25. Deresky, H. (2014). International management: Managing across borders and cultures. (Eight edition). Pearson. Upper Saddle River, New Jersey. 
26. Desantis, D. (2013, September 18). Paraguay's new leader wants back into Mercosur. Reuters. Retrieved from http://www.reuters.com

27. Evans, J., \& Borders, A. L. (2013). Strategically surviving bankruptcy during a global financial crisis: The importance of understanding chapter 15. Journal of Business Research. In press.

28. Filho, P. F. C. (2009). The legal framework for cross-border insolvency in Brazil. Houston Journal of International Law, 32(1) 97-151.

29. Fishlow, A. (2013). A changing development strategy. Journal of International Affairs, 66(2), 17-30.

30. Gough, G. M., \& Venkataramany, S. (2006) Regional economic cooperation. International Business \& Economics Research Journal, 5(2), 49-59.

31. Guerrero, T., \& Gurmendez, T. (2013, February 25). Uruguay. (Mergers and Acquisitions 2013). Retrieved from http://latinlawyer.com/reference/topics/55/mergers-acquisitions

32. Hart, O. (2000). Different approaches to bankruptcy. (Working Paper 7921). National Bureau of Economic Research, 1-18.

33. Hashmi, M. (2012). Determinants of success in international involvement of large U.S. corporations. International Business \& Economics Research Journal, 11(1), 131-135.

34. Haskel, G. (2013, July 15). Two decades on, Mercosur trade bloc fails to live up to expectations. Buenos Aires Herald. Retrieved from http://www.buenosairesherald.com

35. Hill, C. W. L. (2013). International business: Competing in the global marketplace (Ninth edition). McGraw-Hill/Irwin. New York, New York.

36. Holt, T. J. (2007). International bankruptcy and the spirit of comity: New U.S. law encourages cooperation among nations. Business Horizons, 50(2), 105-112.

37. Keller, M. (2012, August 2). What is Mercosur? Americas Society/Council of the Americas. Retrieved from http://www.as-coa.org

38. Italiani, F. (2013, February 25). Venezuela. (Mergers and Acquisitions 2013). Retrieved from http://latinlawyer.com/reference/topics/55/mergers-acquisitions

39. Khanna, T., Palepu, K. G., \& Sinha, J. (2005). Strategies that fit emerging markets. Harvard Business Review, 83(6) 63-76.

40. Kleinheisterkamp, Jan. (2000). Legal certainty in the MERCOSUR: The uniform interpretation of community law. Law and Business Review of the Americas, 6(5).

41. Klonsky, J., Hanson, S., \& Lee, B. (2012). Mercosur: South America's factious trade bloc. Council on Foreign Relations. Retrieved from http://www.cfr.org

42. $\quad$ Lawrence, R. Z., Hanouz, M. D., \& Doherty, S. (2012). The global enabling trade report 2012: Reducing supply chain barriers (Insight Report). Retrieved from World Economic Forum.

43. Latin American Integration. (2013, February 2). The Economist. Retrieved from http://www.economist.com

44. Latin American Geoeconomics. (2013, May 18). The Economist. Retrieved from http://www.economist.com

45. Lee, S. H., Yamakawa, Y., Peng, M. W., \& Barney, J. B. (2011). How do bankruptcy laws affect entrepreneurship development around the world? Journal of Business Venturing, 26(5), 505-520.

46. LeMaster, J., Downey, C., \& Brewerton, F. (2007). Recent developments in selected Asian countries’ bankruptcy laws: Should multinational company strategists be concerned? International Business \& Economics Research Journal, 6(10), 31-38.

47. Li, J., Poppo, L., \& Zhou, K. (2008). Do managerial ties in China always produce value? Competition, uncertainty, and domestic vs. foreign firms. Strategic Management Journal, 29(4), 383-400.

48. LoPucki, L. (1999). Cooperation in international bankruptcy: A post-universalist approach. Cornell Law Review, 84.

49. Martinez, R., \& Iyer, V. (2013). U.S. trade in goods with Latin America (2001-2010): Trends and perspectives. International Business \& Economics Research Journal, 12(5), 503-509.

50. Mason, R. (2012). Cross-border insolvency and legal transnationalisation. International Insolvency Review, 21(2), 105-126.

51. Mercosur remains a fiction, admits Uruguayan foreign minister. (2013, August 13). MercoPress: South Atlantic News Agency. Retrieved from http://en.mercopress.com

52. Mohan, S. C. (2012). Cross-border insolvency problems: Is the UNCITRAL model law the answer? International Insolvency Review, 21(3), 199- 223. 
53. Mussnich, F., \& Peres, F. (2013, February 25). Brazil. (Mergers and Acquisitions 2013). Retrieved from http://latinlawyer.com/reference/topics/55/jurisdictions/6/brazil

54. New Argentine Bankruptcy Law Favors Workers over Creditors. (2011, July 4). Global Insolvency. Retrieved from http://globalinsolvency.com

55. Olivares-Caminal, R., \& Frigerio, G. (2009). Expedited debt restructuring in Latin America: A regional overview. Inter-American Development Bank, 1-20.

56. Osava, M. (2013, July 3). Brazil holds key to door between Pacific alliance and Mercosur. Inter Press Service. Retrieved from www.ipsnews.net

57. Paraguay's President (2013, August 15). BBC News: Latin America \& Caribbean. Retrieved from www.bbc.co.uk

58. Rangan, S., \& Drummond, A. (2004). Explaining outcomes in competition among foreign multinational in a focal host market. Strategic Management Journal, 25(3), 285-293.

59. Rasmussen, B. (2007). Where are all the transnational bankruptcies? American Law \& Economics Association Papers, 40(1).

60. Roett, R. (2010). How reform has powered Brazil's rise. Current History, 109(724), 47-52.

61. Rosas, F., \& Nogueira, L. (2013, January 3). Brazil. (Restructuring). Retrieved from http://latinlawyer.com/reference/topics/56/jurisdictions/6/brazil

62. Sen, A., \& Haq, K. (2010). Internationalization of SMEs: Opportunities and limitations in the age of globalization. International Business \& Economics Research Journal, 9(5), 135-142.

63. Stone, G.R. (2010). Japanese bankruptcy reform and the implications of the civil rehabilitation act. International Business \& Economics Research Journal, 9(2), 37-47.

64. Tanzi, V. (2004) Globalization and the need for fiscal reform in developing countries. Journal of Policy Modeling, 26(4), 525-542.

65. Uruguay calls on Mercosur to sign a free trade agreement with United States. (2013, August 19). MercoPress: South Atlantic News Agency. Retrieved from http://en.mercopress.com

66. Vigevani, T., \& Júnior, H. R. (2011). The grounding of regional integration for Brazil: Universalism, sovereignty and elite perception. Global Society: Journal of Interdisciplinary International Relations, 25(4), 449-468.

67. Westbrook, J. (2002). Multinational enterprises in general default: Chapter 15, the ALI principles, and the EU insolvency regulation. American Bankruptcy Law Journal, 76(1), 1-41.

68. Where is Uruguay's Economy Headed? (2013, May 2). MercoPress: South Atlantic News Agency. Retrieved from http://en.mercopress.com

69. Willa, A., \& Roca, A. (2013, January 7). Argentina. (Restructuring). Retrieved from http://latinlawyer.com/reference/topics/56/jurisdictions/4/argentina

70. Yong, C. A. R. (2010). Providing legal certainty in South America: Can MERCOSUR help? Pace International Law Review Online Companion, 2(3), 1-33. 